\title{
mapping the future
}

Julie Todaro

\section{Recruitment, retention, diversity- cornerstones of future success}

\section{The 2007-2008 ACRL President's focus}

$\mathbf{L}_{\mathrm{p}}^{\mathrm{in}}$

ttle did I know when I prepared my correct I was. My remark "although we've always had a busy and exciting agenda in our association, ACRL leadership and membership have much to do" is an incredible understatement, and I uncover more things "to do" every day. Does this mean that things haven't been happening or that people are leaving things undone? Absolutely not. It means that we are in a rapidly changing world and profession and that our association is a major player in national, state, regional, and local issues and that we are often players in this world on a daily basis. Does this also mean that Board involvement is too time-consuming? Quite the opposite. The staff is extraordinary, electronic communication is a great tool for productivity, and the ACRL process is extremely supportive for planning and decision-making. I highly recommend any Board service and running for and holding an ACRL office.

That being said-besides general ACRL membership business-what initiatives do I want to focus on this year? Other quotes from my election statement work here, as well. "The newest strategic plan is a blueprint for the future with many internal activities for members and a myriad of expanded and new external activities, responsibilities, and partnerships. In addition to the strategic plan, a new structure for ACRL committees, committee leaders, and members, as well as new ways of collaborating with ALA and non-ALA member partners, calls for a new paradigm for focusing on 21st-century directions for legislative initiatives, scholarly communication, ongoing and enhanced recognition in higher education, ongoing definition of our roles in teaching and learning outcomes, intellectual property, access to information, research and publication, and standards and guidelines, to name but a few areas."

So how to choose? Although some of my focus stems from my particular interests, recent membership discussions have pushed me to expand my initiatives. Although my major presidential initiative commitment has been to recruitment and retention, my final list of original initiatives includes two new task forces and a recent presentation, at the 6th National Conference of African American Librarians, sponsored by ALA's Black Caucus convention, has expanded my goals, as well.

\section{Recruitment/retention}

My primary presidential initiative is a commitment to identifying issues and answers to pressing questions about recruitment and retention. To this end, my steering committee goals include designing an ACRL program for the 2008 ALA Annual Conference and creating content to provide guides and pathfinders to successful recruitment and retention to both the profession and the association. The initial groups working on these plans were two workgroups from ALA's new Emerging Leaders (EL). One EL group assisting ACRL created a marketing plan for ACRL's recruitment media and the other EL group created a Wiki with extensive recruitment and retention information. These two products will be expanded to include diversity issues. The initiatives

Julie Todaro is dean of library services and head librarian of the Rio Grande Campus Library of Austin Community College and ACRL president, e-mail: jtodaro@austincc. edu

(0) 2007 Julie Todaro 
include the identification of age-levels, locations, etc. of younger members for retention purposes; assessment of likes, dislikes, needs of younger members for retention purposes; the design and delivery of columns/content for publishing mechanisms for younger members for recruitment and retention; the design and delivery of recruitment information for younger members; and the design and delivery of program(s) for Presidential Focus/retention at the 2008 ALA Annual Conference in Anaheim, California.

\section{Two new task forces}

There have been many discussions in the past decade (and I'm sure in decades before) about the role of the academic library in higher education/the academy and on campuses; the perception of the academic library in the academy and on campuses; and internal and external partnerships and relations, such as academic libraries and IT departments. Last year's ACRL Technology Summit was designed to begin the discussion, and we have many more questions and recommendations for academic leadership. Recent programs (such as Pam Snelson's excellent presidential program last year) have added to the discussion.

To this end, I have appointed the Task Force Positioning the 21st-Century Library in the Competitive Academy: Why We Can't Wait. The charge of the group is to identify ways to position the library in the competitive academy that can be undertaken by members and by ACRL. Elizabeth Henry (assistant director for public services for university libraries at the University of Missouri-Kansas City) has accepted the chair position. Her goals include:

- identifying challenges facing academic librarians related to the library's position on campus,

- recommending short- and long-term aggressive activities that members/administrators can engage in to strengthen the library's position on campus, and

- recommending short- and long-term proactive programmatic initiatives that ACRL can undertake to support members addressing these challenges.

Although task forces find varieties of ways to meet goals, I don't envision major surveys of membership nor hearings or forums, although these may be ways to vet the recommendations of the task force. What I do see is a think tank of experts brought together to identify recommendations that might be realized as "must" statements or markers of today's or possibly tomorrow's most successful academic libraries. The task force will design the approach, including how to couch or set the context of recommendations. I am challenging the task force to provide recommendations or statements for libraries and library leadership, but also to provide (for each recommendation/statement) a corollary such as "ACRL's role in support/leadership of this . . . would include ...."

An additional initiative specifically for the association is the creation of a Task Force on Not-for-Profit Entrepreneurial Best Practices.

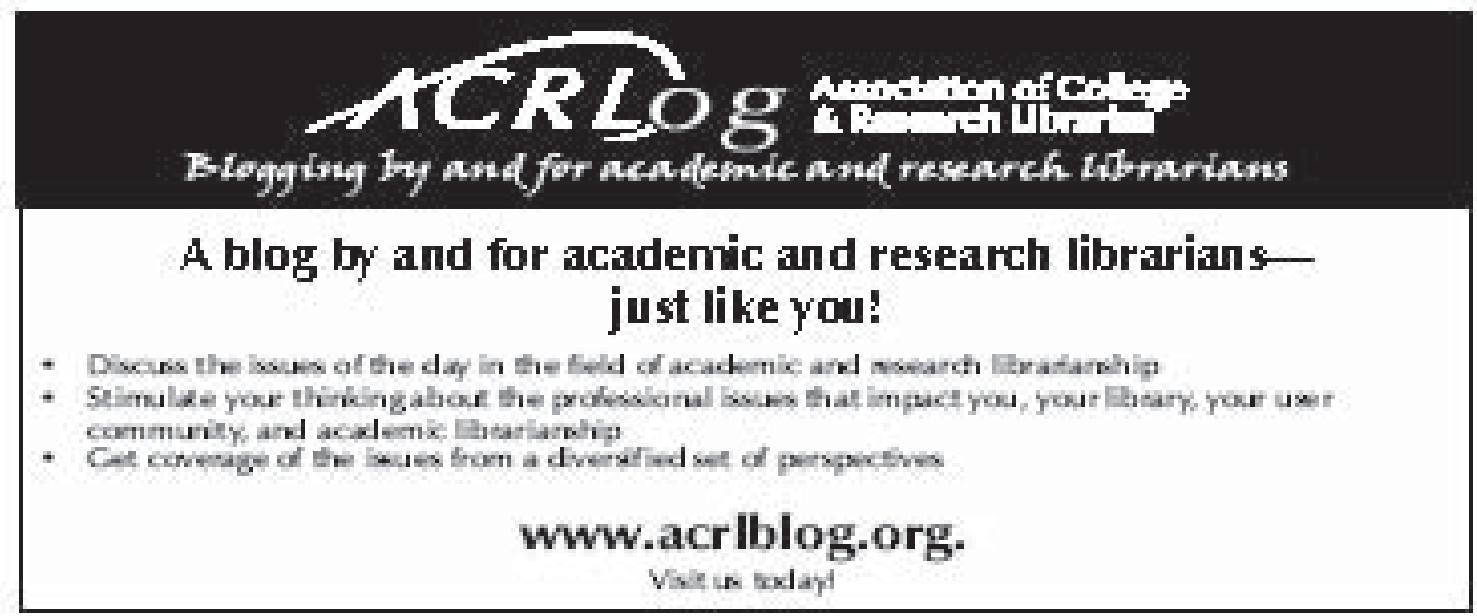


This task force was established with the following charge: to identify entrepreneurial activities that would be appropriate for ACRL to undertake to expand ACRL's revenue streams. Specific tasks include identifying best practices that not-for-profits use to generate alternative sources of revenue; matching these best practices to ACRL structure, staffing, membership, etc. to select those most likely to be effective in the ACRL environment; and prioritizing recommended fundraising activities.

\section{Expanded goals}

After reviewing the ACRL white paper "Achieving racial and ethnic diversity among academic and research librarians"1 and the EL marketing plan recommendations for ACRL recruitment material, I expanded my recruitment and retention initiatives to be more specific regarding the inclusion of diversity materials.
I prepared a companion piece to the ACRL white paper ${ }^{2}$ as a the handout to accompany my presentation at ALA's Black Caucus 6th National Conference. Ideas and initiatives for education, publications, marketing, and discussions presented in the handout expand recruitment, retention, and diversity initiatives and provide goals and outcomes that cannot be completed in one year, but can provide possible directions for membership discussion as well as create the groundwork for future work.

As members begin discussions on these important issues, they should note that ACRL has much content in the strategic plan, in committee, taskforce and chapter initiatives - to name but a few areas — and is committed to expanding its focus even more through online, conference, and in-person workshop curriculum design on recruitment, retention, and diversity for both managers and front-

(continues on page 510)

\section{ARL/ACRL announce first regional Institute on Scholarly Communication}

The Association of Research Libraries (ARL) and ACRL announce the rst regional Institute for Scholarly Communication, hosted by the Consortium of Academic and Research Libraries in Illinois (CARLI), December 5-7, 2007, in Chicago.

This immersive learning experience prepares participants as local experts within their libraries. Participants, who are encouraged to attend in teams, will become uent with scholarly communication issues and trends and begin developing outreach plans for their campuses.

A regional event allows us to support institutions that would not, for whatever reason, attend a national event, commented Kara Malenfant, ACRL s scholarly communications and government relations specialist, and CARLI makes a wonderful rst partner.

Karla Hahn, director of ARLs Of ce of Scholarly Communication, noted, We see this move to a regional event as a natural evolution in the life of the institute. It will enable us to refocus our national efforts to meet the changing needs of the library community.

Acceptance to the Illinois ARL/ACRL Institute on Scholarly Communication is competitive; participation is limited to 100 to ensure an environment that fosters group interaction and active participation. Institutions from Illinois will receive preferred consideration, and seats are reserved for 20 participants outside the state. Applications will be accepted until September 14, 2007.

Find complete details on the CARLIWeb site at www.carli.illinois.edu/institute07. html

Consortia or other institutions that may be interested in hosting the next regional Institute on Scholarly Communication should contact Julia Blixrud,ARL s assistant executive director of external relations, jblix@arl.org. 
and through the arts. Access: http://pzweb. harvard.edu/Research/PatThk.htm.

- Teaching and Learning with Digital Video. Created by Greg Marten of Lenawee Independent School District, this site provides links to selected resources on digital video in education. Access: http://www.kn.pacbell. com/wired/fil/pages/listdvma.html.

- The On-Line Visual Literacy Project. This is a site that was created for a project in 1994 and is a guide to the basic elements of visual communication like shape, scale, line, direction, value, etc. Access: http:// www.pomona.edu/Academics/courserelated /classprojects/Visual-lit/intro/intro.html.

- The Visual Literacy Toolbox: Learning to Read Images. This site provides a series of links to exercises and tutorials to "help faculty customize their curricula to incorporate visual literacy in ways that suit their individual instructional needs." The focus is on the visual arts. Access: http://www.arhu. umd.edu/vislit/index.html.

- Visual Literacy K-8. This site is full of resources to help teachers. Examples of visual texts include maps, tables, timelines, and storyboards. The site is maintained by authors Steve Moline and David Drew. Access: http://k-8visual.info/.

- VUE: Visual Understanding in Education. VUE "conducts educational research focused on aesthetic and cognitive development that results from interaction with art. Based on its findings, VUE develops programs for schools and museums, principally Visual Thinking Strategies (VTS)." Many of the articles are available in PDF. Access: http://www.vue.org/.

\section{Wikis and blogs}

- Eye to I: Visual Literacy Meets Information Literacy. This is the joint Arts/Instruction Section program that was presented at the 2007 ALA Annual Conference in Washington, D.C. The blog includes virtual posters from a variety of authors and disciplines. The poster sessions will be available through December 2007. Access: http://eye2i.wordpress.com /program-planning-committee/.
- Teaching Online Journalism. This blog by Mindy McAdams explores how visual literacy is an important component when telling a story. The author asks if words and images need each other to make sense, or if they can they be used alone. Access: http:// tojou.blogspot.com/2007/05/visual-literacy -in-multimedia.html.

- The Strength of Weak Ties. This site explores how to use Flickr to analyze images or illustrate writing. The author asks "What if every student was given the same piece of writing and was asked to apply photography from Flickr?" Access: http://jakespeak. blogspot.com/2005/05/sandburg-meets-flickr. html.

- NJAET. This blog by Cathy Grimaldi explores how and why images affect us. Access: http://njaet.blogspot.com/2007/04 /visual-literacy.html.

- Visual Literacy and 21st Century Skills. By David S. Jakes, this wiki covers various aspects of visual literacy. The author uses images and videos throughout. Access: http://visuallit.pbwiki.com/FrontPage. z

("Recruitment..." continued from page 506)

line librarians. Current ACRL information is being assessed and plans for revisions are underway for marketing, public relations, and related materials. Strategies for institutionalizing ideas are being discussed and include assessing the current research agenda, designing additional items for it, having ACRL units develop action plans to carry out these initiatives, strengthening conference planning practices, and benchmarking best practices in associations and in the field of library and information science.

We have our work cut out for us. I'll be happy if we complete some of the plans I've outlined and develop roadmaps for the future.

\section{Notes}

1. Visit www.acrl.org/ala/acrl/acrlpubs /whitepapers/ACRL_AchievingRacial.pdf.

2. See www.ala.org/ala/acrl/acrlpubs /whitepapers/culturekeepers.pdf. z 